\title{
OGÓLNOPOLSKA KONFERENCJA NAUKOWA KANONICZNO-LITURGICZNE ASPEKTY ZAWIERANIA MAŁŻEŃSTW MIESZANYCH I IM PODOBNYCH. WARSZAWA, 23 KWIETNIA 2014
}

W dniu 23 kwietnia 2014 roku odbyła się Ogólnopolska Konferencja Naukowa pt. Kanoniczno-liturgiczne aspekty zawierania małżeństw mieszanych i im podobnych zorganizowana przez Wydział Prawa Kanonicznego Uniwersytetu Kardynała Stefana Wyszyńskiego w Warszawie.

Konferencję rozpoczął dziekan Wydziału Prawa Kanonicznego UKSW ks. dr hab. Henryk Stawniak, prof. UKSW. Następnie do uczestników zostało skierowane słowo rektora UKSW ks. prof. dr. hab. Stanisława Dziekońskiego.

Pierwszej, przedpołudniowej sesji przewodniczył ks. prof. dr hab. Tomasz Rozkrut - dziekan Wydziału Prawa Kanonicznego UPJPII w Krakowie. W tej części jako pierwszy swój referat przedłożył bp dr Krzysztof Nitkiewicz. W swoim wystąpieniu zatytułowanym: Przygotowanie do zawarcia małzeństwa pomiędzy wiernymi Kościoła łacińskiego i katolickich Kościołów wschodnich przypomniał, że przygotowanie do zawarcia małżeństwa sakramentalnego należy do tradycyjnych działań duszpasterskich Kościoła. Podstawy prawne oraz konkretne regulacje prawne dotyczące wymogu przygotowania do małżeństwa znajdują się w przypadku wiernych Kościoła łacińskiego w Kodeksie prawa kanonicznego, kan. 1063-1070, zaś w przypadku wiernych katolickich Kościołów wschodnich w Kodeksie kanonów Kościołów wschodnich, kan. 783-788. Na obszarze Polski obowiązuje Instrukcja o przygotowaniu do zawarcia małżeństwa w Kościele katolickim z 5 września 1986 roku. Prelegent omówił przeszkody, możliwości dyspensowania od nich w obydwu kodeksach. Podjął także zagadnienie zaręczyn, instytucji regulowanej prawem partykularnym oraz liturgii zawarcia małżeństwa, której w przygotowaniu do zawarcia małżeństwa należy poświęcić więcej czasu.

Drugi referat przedłożył o. dr hab. Marek Saj, prof. UKSW: Zawarcie małzeństwa z niewierzacym lub niepraktykujacym. Autor referatu omówił kwestie osób niewierzących i niepraktykujących, zwłaszcza jeśli chodzi o ich stosunek do wiary i Kościoła, a następnie kwestie przygotowania do zawarcia przez nie małżeństwa kanonicznego oraz obrzędu jego zawarcia. Ważną uwagą, jaką poczynił, jest stwierdzenie, że osoba, która nie praktykuje, nie może być nazwana apostatą; staje się nim, kiedy wyrazi lub uzewnętrzni swoją wolę zerwania więzi wiary, sakramentów i zwierzchnictwa kościelnego. Przygotowując do małżeństwa osoby niewierzące lub niepraktykujące, szczególną uwagę należy zwrócić na ich wiarę. Ich postawa w sposób oczywisty przeczy wierze. Do prośby o zezwolenie do asystowania przy 
małżeństwie katolika z osobą niewierzącą lub niepraktykującą prawodawca kodeksowy wymaga dołączenia tzw. rękojmi. Norma ta pochodzi z kanonów dotyczących małżeństw mieszanych. Jeśli chodzi o obrzęd liturgiczny, to nie przewiduje się żadnych modyfikacji. Zazwyczaj dokonuje się on podczas mszy świętej lub poza nią.

Ostatni referat w sesji przedpołudniowej wygłosił ks. dr Tomasz Jakubiak z Papieskiego Wydziału Teologicznego w Warszawie: Prawno-liturgiczne aspekty zawierania matżeństw z osobami, które formalnym aktem wystapiły z Kościoła. Prelegent na samym początku zaznaczył, iż przygotowanie do zawarcia małżeństwa, gdy jedna ze stron formalnym aktem odstąpiła od Kościoła, jest niezwykle złożoną kwestią. Zbiega się tu wiele elementów. Najważniejszymi są: prawo naturalne człowieka do małżeństwa, prawo kościelne dotyczące zgody małżeńskiej oraz zakaz przystępowania do sakramentów dla ekskomunikowanych. W swoim referacie Autor podjął następujące zagadnienia: przygotowanie bezpośrednie do małżeństwa; rozeznanie sytuacji prawnej nupturienta; metryka chrztu; rękojmie; zapowiedzi przedślubne; sakramenty bierzmowania, pokuty i Eucharystii; nauki przedślubne; spisanie protokołu kanonicznego badania narzeczonych; stwierdzenie stanu wolnego, zgoda małżeńska oraz forma zawarcia małżeństwa.

Drugiej sesji przewodniczył ks. dr hab. Wiesław Kiwior, prof. UKSW, a jako pierwszy referat w tej części wygłosił ks. prof. dr hab. Leszek Adamowicz (KUL): Aspekt prawno-liturgiczny zawarcia malżeństwa katolików z prawosławnymi. Ks. Adamowicz zaznaczył na wstępie, że wschodnie Kościoły niekatolickie, w tym Kościoły prawosławne, uznają sakramentalną godność małżeństwa ochrzczonych i z tej racji są bliskie Kościołowi katolickiemu. Zdaniem teologów rosyjskiej Cerkwi prawosławnej ważność i legalność sakramentów jest w zasadzie utożsamiana. W dalszej kolejności profesor z Lublina podjął następujące zagadnienia: ustalenie faktu chrztu i stanu wolnego oraz wolności od przeszkód; forma kanoniczna - kapłan błogosławiący i świadkowie. W przypadku zawierania małżeństwa w Cerkwi należy pamiętać, że nupturient - katolik winien uzyskać od swojego ordynariusza miejsca dyspensę od formy kanonicznej, która wymagana jest ad liceitatem. Następnie Autor podjął kwestię relacji małżeństwa i Eucharystii; kalendarza liturgicznego, tzn. kiedy nie wolno zawierać małżeństwa w Cerkwi oraz kwestię legalizacji małżeństw zawartych w Cerkwi.

Kolejny referat wygłosił ks. prof. dr hab. Ginter Dzierżon (UKSW) na temat: Realizacja warunków dotyczących nupturientów w przypadku zawierania malzeństwa $z$ wiernymi Kościoła Ewangelicko-Augsburskiego w Polsce. Prelegent wyjaśnił, że organem ustawodawczym Kościołów protestanckich są synody, które są reprezentantem wiernych. W Kościele Ewangelicko-Augsburskim nierozerwalność stanowi istotny przymiot małżeństwa. Doktrynalnie rozwód traktowany jest w kategoriach tolerowanej konieczności. Następnie zostały omówione zagadnienia odsunięcia niebezpieczeństwa utraty wiary oraz obowiązek ochrzczenia i wychowania dzieci w duchu swojego Kościoła. W tym przypadku ustawodawca katolicki i ewangelicki nakładają na swoich wiernych podobne zobowiązania. 
Trzeci referat w tej sesji wygłosił ks. prof. dr hab. Wojciech Góralski (UKSW): Przygotowanie do matżeństwa katolika z nieochrzczonym. Prof. Góralski swoje zagadnienie przedstawił w dwóch punktach. Najpierw uwypuklił znaczenie wstępnej rozmowy duszpasterza z narzeczonymi i rolę katechezy przedślubnej, a następnie omówił kanoniczne badanie przedślubne i dalsze czynności prawne poprzedzające zawarcie małżeństwa i związane $\mathrm{z}$ jego zawarciem.

Po dyskusji głos zabrała dr hab. Urszula Nowicka (UKSW), która podsumowała i zamknęła Konferencję, dziękując prelegentom za wygłoszenie referatów, a wszystkim uczestnikom za przybycie.

ks. Robert Kantor 
